\title{
Organizational Reputation within the Framework of Total Quality Management: the University of Jordan as a Model
}

\author{
Enas Ahmed Al Shuqairat ${ }^{1}, \&$ Mohammed Salem Al-Shura ${ }^{1}$ \\ ${ }^{1}$ The World Islamic Sciences \& Education University, Jordan \\ Correspondence: Enas Ahmed Al Shuqairat, The World Islamic Sciences \& Education University, Jordan.
}

Received: October 11, 2021

Accepted: October 25, 2021

Online Published: November 5, 2021

doi:10.5539/ibr.v14n12p41

URL: https://doi.org/10.5539/ibr.v14n12p41

\begin{abstract}
This study aimed to identify the organizational reputation of the University of Jordan (a model) in the context of its application of total quality management. The study sample consisted of (350) faculty members at the University of Jordan. The study also used the (questionnaire) tool that it developed is collect data after verifying its validity and reliability.

The results of the study showed that there is a high degree in the achievement of the University of Jordan for Total Quality Management, which was reflected on its reputation, and that there were significant statistically significant differences at the level $(\mathrm{a} \leq 0.05)$ in the university's reputation as a result of its application of the principles of total quality management, which was explained by the high standards of the organizational reputation variable, starting with In terms of (creativity/strength of financial position/quality of service/social responsibility), the criterion of attractiveness was the least effective.

Among the recommendations that came: maintaining the application of total quality management in the University of Jordan more effectively with continuous development and improvement, and working on marketing the University of Jordan to further improve the image in the minds of beneficiaries (existing and new prospects).
\end{abstract}

Keywords: total quality management, organizational reputation, university of Jordan

\section{The Introduction}

The University of Jordan occupies a great position among the local and Arab universities. How is it not? It is the mother, the first and the most important of Jordanian universities. Since it began its educational journey, it has witnessed the events and fluctuations that have occurred in the world today from a huge technological and knowledge revolution, in addition to the arrows of globalization that affected the education sector like others. From the service and production sectors, it has become even more urgent to respond quickly to these changes, a matter that carries with its efforts to search for everything that can present its educational and academic outputs in the best and brightest picture. And the University of Jordan, like other institutions that provide services, has incorporated total quality management into its strategic and operational plans to jump towards renewal, change, and improvement in its services provided to go beyond everything old and stereotypical in its outputs. This is due to its tireless pursuit of the developmental, economic, and urban progress required by society.

The organizational reputation is considered one of the most important intangible assets that institutions (service, production, and educational institutions as well) seek to acquire to support and strengthen their capital. In addition, today it is measured by global and local indicators and standards, in addition to the important role, it plays in shaping the final mental image of the institution. In the minds of the stakeholders of its services to translate it into their behavior and loyalty towards it. And because the higher education sector is important (Kooli, 2019),

\section{The Study Problem}

In light of the big developments and changes that are taking place today in the world of revolution and knowledge, competition has become intense between universities, in the number of students of different nationalities registered in them, and in the excellence of their educational and administrative staff, the curve of competition between Jordanian universities has begun to rise in light of international classifications that have become an icon for measuring reputation Through specialized companies and bodies that entered the higher education sector to set international rankings for universities, related to their performance, academic reputation, employment rates, 
scientific publication percentage and other indicators (Shakhatra and Tarawneh, 2019).

Researchers today believe that the reputation of Jordanian public universities has been shaken their image from before, not only locally, but also among Arab universities, because the modern experience of the international rankings of universities is a modern and contemporary experience that universities in general use to raise the level of their reputation, but it is still within a framework limited to Some Narrow Limited Indicators (Yasin, 2015; Shakhatra and Tarawneh, 2019).

Perhaps many previous types of research talked about total quality management in detail and in the educational sector as well, and this does not interfere with us discussing again today this topic, but to find the impact of the application of total quality in the organizational reputation of the University of Jordan, which aspires to have its name among the list of prestigious international classifications Which the world's most prestigious universities have reached

\section{Study Objective and Question}

This study aims to measure the impact of the University of Jordan's application of total quality management and its impact on its reputation, from which the following two questions emerge:

1. What is the level of application of total quality management in its dimensions at the University of Jordan?

2. Is there a statistically significant effect at the level $(\alpha \leq 0.05)$ for the application of total quality management on the organizational reputation of the University of Jordan?

\section{The Importance of the Current Study}

We hope from the results of this study to be an indication of weaknesses and strengths in the application of the principles of total quality management at the University of Jordan so that there is room for correcting weaknesses and strengthening strengths for a better result in the future.

\section{Study Form}

The study model was formulated, in order to describe the relationship between the study variables represented by the application of total quality management with its dimensions on the organizational reputation of the University of Jordan.

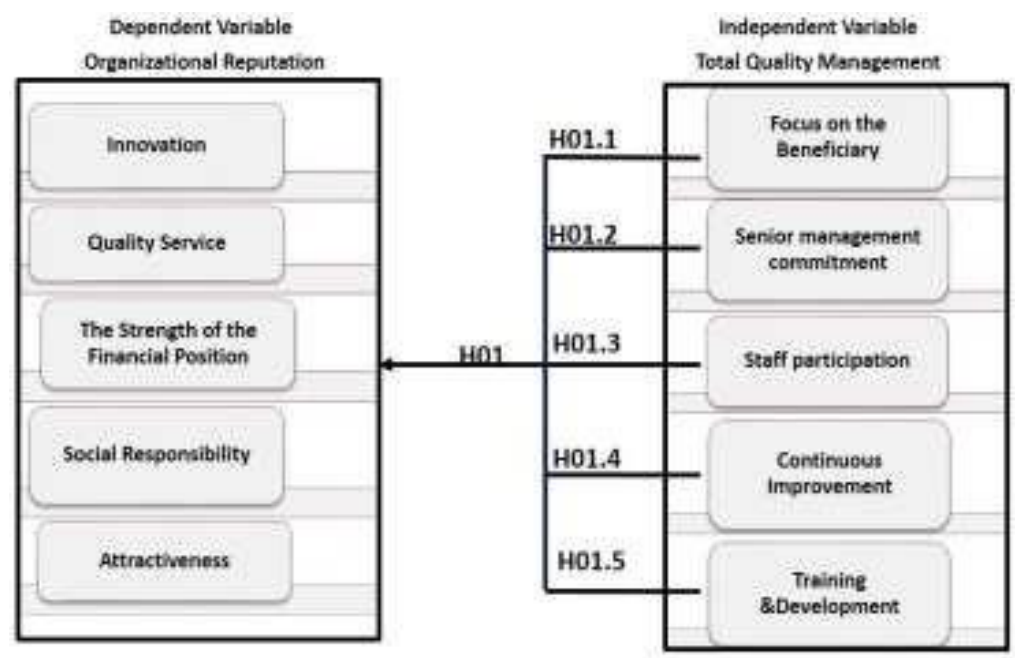

Figure 1. The default model for the study

\section{Study Hypotheses}

The main hypothesis:

There is no statistically significant effect at the level $(\alpha \leq 0.05)$ of the application of total quality management with its dimensions (focus on the beneficiary/ commitment of senior management / continuous improvement/ participation of working individuals / training and development) on the organizational reputation with its combined dimensions (creativity / service quality /Strength of financial position/social responsibility/gravity) at the University of Jordan? 
The following sub-hypotheses emanate from it:

(H01.1) There is no statistically significant effect at the level of

significance $(\alpha \leq 0.05)$ for total quality management with its dimensions on organizational reputation according to the creativity dimension at the University of Jordan.

- $\quad$ (H01.2) There is no statistically significant effect at the level of significance $(\alpha \leq 0.05)$ for total quality management with its dimensions on organizational reputation according to the service quality dimension at the University of Jordan.

- $\quad$ (H01.3) There is no statistically significant effect at the level of significance $(\alpha \leq 0.05)$ for total quality management with its dimensions on organizational reputation according to the dimension of the strength of the financial position at the University of Jordan.

- $\quad$ (H01.4) There is no statistically significant effect at the level of significance $(\alpha \leq 0.05)$ for total quality management with its dimensions on organizational reputation according to the dimension of social responsibility at the University of Jordan.

- $\quad$ (H01.5) There is no statistically significant effect at the level of significance $(\alpha \leq 0.05)$ between total quality management with its dimensions on organizational reputation according to the dimension of attractiveness at the University of Jordan.

\section{The Limits of the Study}

This study will be limited to faculty members of all academic ranks at the University of Jordan during the summer semester of the academic year 2020/2021, and the results of the study will be specific to the validity and stability of the questionnaire that has been developed, in addition to a statement of objectivity derived from the respondents (the study sample) and their scientific integrity, And the true degree that represents the selected sample from the study population. Accordingly, the results of this study are not and will not be valid except for the community represented by the study sample, which is (the University of Jordan).

\section{Terminology of Study}

Total Quality Management: Meeting customer needs and reasonable expectations. It is a science and an art based on: accepting change, the importance of strategic planning, paying attention to the needs of the beneficiary of the product or service, absorbing modern technologies as an influential factor, providing a correct environment that allows workers to participate and be creative in work, emphasizing the importance of the human element in the success of work (Atiya, 2015, 22).

It is defined procedurally: continuous improvements that affect the inputs and outputs of the work of universities, which are sought and adopted by the strategies of the senior management in their executive and strategic plans on an ongoing basis to improve the quality of their outputs.

Organizational reputation: the beneficiaries' and customers' assessment of the institution's ability to meet their requirements, and their impressions about its business and policy, the more positive their opinion is, the more they support the institution and continue their relationship with it (Eckert, 2016).

It is defined procedurally: it is to achieve the clear objectives of evaluating the internal and external performance of the organization/university so that the beneficiaries (students and the local community) have an impression and positive mental image of performance excellence and quality of outputs.

The University of Jordan: The University of Jordan was established in 1962, as the university seeks to be distinguished academically and pioneering in order to reach advanced international levels. The University of Jordan has put in the hands of its students a wide choice of academic programs, providing them with a choice of more than (250) academic programs offered by (24) colleges in various disciplines. Where the university offers at the bachelor's level (94) different programs in many fields. At the postgraduate level, it offers (38) doctoral programs, (111) master's programs, (16) programs in higher specialization in medicine, and a program in higher specialization in dentistry, and (3) diploma programs.

The University of Jordan's quest to reach the highest ranks of excellence does not stop, as it applies the principles of total quality in its programs and strategies, So it reached the top of the rankings, as it is according to the QS classification at 600, and among the best (10) Arab universities, and five stars according to the QS Ranking and its faculties. It has many private certifications and international accreditations.

\section{Theoretical Framework and Previous Studies}

Today we see the continuous efforts of universities to enhance their presence in the education sector in the best 
way. As well as its quest to provide outputs that meet the wishes of stakeholders and can compete strongly, this matter made it more interested in the application of total quality management, which has become the key to change towards better improvement and development (Al-Nuaimi et al., 2020).

\section{The concept, importance and principles of total quality management}

The concept: which emerged and grew up in Japan, at the beginning of the fifth decade of the twentieth century, and then began to spread and prevail in the countries of Western Europe and North America, later became the focus of attention and the topic of the era, until it was embodied in an integrated approach of modern management approaches. Like any concept that has been affected by the arrows of globalization, technology, and tremendous knowledge, the concept of total quality management came to achieve the highest goal of stakeholders, which is full satisfaction and acceptance, by providing the finest and best services, with the contribution of all workers in the improvement and development processes (Khiouka and Al-Obaidi, 2020), Considering that total quality management is a highly participatory process among all working individuals to achieve the ultimate goal of stakeholders, represented by: higher quality,less time (Ghoneim, 83, 2018).

Like other institutions and organizations, universities consider the concept of total quality management an important concept in their strategies, policies, programs, and activities, as total quality management is represented by a set of multiple processes that aim through it to raise the performance of its academic and administrative staff, especially (faculty members), and to develop its plans and teaching programs (Theoretical and applied) to be distinguished in providing its educational services and positively reflect on its educational outcomes and reputation (Al-Sarhan, 2021).

Importance and Principles: The importance of total quality is reflected in its principles, which are of great weight and importance in the practical application framework in various organizations (service, productivity, educational) alike. The support and commitment of senior management are one of the important principles of total quality management and in the absence of this principle, there is no real for quality , as it is sufficient here as a slogan that includes management strategies and plans without implementation. Wherever there is interest and commitment, quality finds its strength and effectiveness to begin the journey of change towards the desired development and improvement (Belkacemi and Jamil, 2020).

As for continuous improvement, which is the essence and content of total quality management, it is a philosophy based on making all processes and procedures appear in the best way and efficiency, which makes this improvement clear in the organization's body closely linked to its organizational capabilities, (Al-Habib, 2019, 130-140) (Kooli et al,2019).

The importance of focusing on the beneficiary is no less important than other principles of quality, as meeting the needs and desires of the beneficiary is important because it generates a feeling of satisfaction towards the organization. And work to constantly update it through continuous communication with them (Stevenson, 2018: 394).

Since the focus comes first on the beneficiary, it also comes to the organization's employees through their participation in improvement and development programs, as workers at all levels of management are primarily responsible for the success of quality management through their understanding and awareness of the culture of quality and the excellence and efficiency it carries in its folds (kooli\& Abadli,2021). The overall performance of them and the organization (Griffin, 2016:617), in addition to that, training and development is an important principle through which the organization seeks to provide good human resources, train and qualify it to become an active member in the process of implementing total quality management efficiently. by rehabilitating all employees of the organization and educating them with the behaviors and skills that apply to their duties, and which enhance their self-confidence, making them able to participate in the appropriate decision-making process (kooli\& Abadli,2021); (Khiyouka and Al-Obaidi, 2020).

\section{Total Quality Management in Universities}

Total quality management is a guarantee that universities will obtain outputs that meet the needs of society on an ongoing basis, in addition to being an important factor that raises the level of satisfaction with them, achieves the competitive advantage they seek, and raises their reputation to the refineries of prestigious universities, as obtaining some international certificates now requires the application of the system Total Quality Management (Abu Al-Nasr, 2015).

The universality and comprehensiveness of this system, which includes all fields, being one of the features of the modern era, raises the level of performance that works on the principle of optimal use of available resources while reducing waste and waste. This system maintains the reputation and vitality of the educational institution, achieves 
the requirements of the labor market, as well as increases the satisfaction of faculty members and students, and thus works to improve the quality of university graduates, maximize its role and enhance its competitive position and reputation among its peers (Omran et al., 2020).

The researchers believe that competition is intense between different universities, and it will remain in this case with the continued tremendous progress in technology and knowledge. Perhaps the most important reason for that:

1. The competitive image of local university graduates is absent in the market

\section{And that competition between local and Arab university graduates is still weak}

3. And that there is a shortage in the market share of Arab companies in the global market because that the human resource has a traditional and non-renewable stereotype.

4. The number of graduate students in some specializations is saturated in a way that does not meet the needs of the market

5. Add to that the increasing level of unemployment among graduates (Abdul Rahim et al., 2020).

Organizational reputation:

(Shakhatra \& Tarawneh, 2019) refers to the concept of reputation defined by (Coombs) as the impressions received by the masses through symbols and channels of communication and communication with the institution, meaning that it is the last impression that is taken of this institution in the minds of the public. While (Kawengian, et al, 2019) shows that the organizational reputation is an integrated mixture of (expectations and final perceptions) of the opinion of the beneficiaries of the institution (customers / suppliers / workers in the same institution / investors / local community) about its services, entity and behavior towards them from during their direct experiences with it.

The researchers define organizational reputation as the initial impression of the institution, which is represented by its logo and organizational entity, its relationship with stakeholders, and its role in the renaissance of the local community it represents.

The importance and advantages: The researchers consider the organizational reputation as a window to achieve goals, opportunities, and competition in the life of institutions today in a world marred by fluctuating turmoil in all political, economic, social, and political aspects. With the entry of this concept into other administrative concepts, the research that dealt with this concept is still limited in the practical and applied aspects (Madi and Al-Bashiti, 2020).

Today, we see major institutions facing crises from all directions due to the frightening acceleration caused by globalization and the technological and knowledge revolution, which means that they face an unknown fate if they do not respond quickly to this imminent danger.

Looking at this expected challenge that these institutions will face, we see, on the other hand, that the organizational reputation has been significantly shaken as a result of the crises that the institutions experienced in the course of the events of the twentieth century, and from this gap, these institutions began to look more deeply than before and began to feel the flaws In its entity and in its tangible and intangible assets, of which reputation is one, if not the most important, for this matter, it began to search and seek to find what is familiar and similar to its counterparts in providing (services, products, etc.) to what is unfamiliar through the management of its organizational reputation As an integral part of its various activities within its organizational entity (Castillo et al, 2019).

And what (Castillo et al, 2019) points out in his study to the importance of organizational reputation, which in turn helps motivate the performance of employees in the organization and the active participation that they perform through their commitment to work better, considering them to be an important resource in the organization, through which the goals and objectives are achieved. The study also shows that the organizational reputation increases the state of social compatibility with the local community. The perceptions of the local community increase the organization's chances of survival and success in the community it represents. Referring to the issue of organizational reputation that stems from the interest in the public benefiting from its services and products, focusing on them to realize the value of the services and products provided by the institution to them, and to build bridges of communication with them, to be a source of feedback for the organization to indicate weaknesses and strengths in its outputs provided to them, through which it acquires its image and her ultimate reputation (Amair and Salah al-Din, 2017).

Add to its features, which are considered a strength and a shield in the crises experienced by the organization, the fact that a good reputation protects the organization from falling into mistakes, due to the reliability it enjoyed through the direct relationship with stakeholders, and their constant readiness to stay with it on a permanent basis. 
Perhaps the dynamic characteristic that characterizes the reputation and its ability to permanently and quickly interact with the internal and external environment variables increases its importance and makes it measurable and evaluated by following many methods to find out the strength of its image and its reflection in the beneficiaries of its services (Kawengian, et al., 2019), (Kawengian, et al., 2019), ( Tong et al., 2019).

\section{Organizational Reputation for Universities}

While the importance of the organizational reputation of universities is considered an important criterion and a prominent indicator on which it depends in its evaluation by the relevant institutions and bodies, the local community it seeks to serve, and the stakeholders who support it in providing its services with a distinctive quality, and in attracting the beneficiaries of its services in the first place (students) and investors (Willems, 2019).

The importance of reputation for universities in general and for the University of Jordan (research orbit) is an important focus of discussion, as it is the mother university in Jordan, which has received wide attention over many years, and gained a local, Arab and international reputation as well, so it was necessary to maintain this reputation and strengthen its position. And its entry into global competition with the most prestigious international universities, which gained wide fame and occupied the ranks of international rankings from the most prestigious educational institutions and specialized institutes, so it had to maintain this reputation through the administrative procedures that it brought about through its application of total quality management in its strategies.

Through the study tool, the researchers seek to highlight the role of total quality management in enhancing the reputation and prestige of the University of Jordan, to highlight weaknesses and strengths in its application and management enhanced by the philosophy of total quality, and how it had an impact on its reputation and standing among its counterparts locally and in the Arab world.

\section{Previous studies}

The researchers reviewed many studies related to the subject of their study, which was subjected to many of those who preceded the research and scrutiny to gain more knowledge, and we decided to present some of them because they are related to the dimensions of the current study.

The researchers reviewed the study (Abu Asbaa, 2020), which was concerned with knowing the role of total quality management in achieving a competitive advantage in Yemeni private universities. Competitiveness) in detail, in order for the study to conclude with results that the researcher summarized by mentioning the principles of total quality and its role in achieving competitive advantage in Yemeni private universities.

The study (Hamidi et al., 2020), whose goal was to Awareness Algerian university administrators about the role of total quality management as a modern method for improving the performance of their universities, focused on the issue of improving service quality, which obliges universities to search for ways to help them achieve their goals. This study followed the descriptive analysis method, by studying the variables (the principles of total quality management, and improving the performance of the university), as 33 questionnaires were distributed to the professors of the University of Batna1. The study found the most important results, the most important of which is that the principles of total quality management (senior leadership and the participation of faculty members) positively affect the performance of universities.

As for the objective of the study (Al-Haj Adam et al., 2020) to evaluate the performance of higher education institutions from the perspective of total quality management, which followed the descriptive survey approach, in describing the variables (performance evaluation, and total quality management), and the sample reached (600 items) for the study population. Which included (faculty members in general, and those in administrative positions - deans, heads of departments, and managers) in (3) universities. Which led the researchers to important results: That there is a weaknessin adopting the philosophy of performance evaluation by the administrations of Sudanese government universities, which contributed to the failure to develop the general performance of the teaching staff and administrators in them, and that there is a clear absence of plans related to evaluation, while it was found that there is support and support from the higher management of continuous evaluation, which contributed In developing curricula and providing them with relevant specialized knowledge and skills.

While the study (Zoglash, 2020) aimed to highlight the importance of the application of total quality management in Arab universities, and how it can face globalization and the changes it brought about, which imposed on all sectors, regardless of service or productivity, restrictions and challenges to keep pace with, by identifying the most important variables of this research ( Total quality, higher education, and information technology), and by following the descriptive-analytical method that is based on the principle of collecting, classifying and evaluating evidence in terms of importance and weight for the subject of the phenomenon under study, and then giving the appropriate analysis after evaluation. The result of the research came to confirm the role of globalization in 
imposing the changes that forced higher education institutions to forcibly submit to them, to consider their educational outputs as basic inputs in other non-educational sectors, in addition to highlighting the importance of applying the principles of total quality in the educational sector.

In their research and their quest to find out the obstacles that faced the application of total quality management at Sebha University, by studying the problems faced by the faculty staff in the Faculty of Economics and Accounting, the researchers found that there are moral relationships between most of the obstacles and the application of total quality management, which ranged from the biggest obstacles to the least impact (the funding obstacle). Scientific research, community service, faculty, and senior management, and finally the educational curriculum obstacle), which was revealed to us by a study (Imran et al., 2020).

Back to the findings of other researchers who have been striving to know the reality of the administrative procedures practiced to raise the organizational reputation of our Jordanian public universities from the point of view of their administrations of academics, we find that the reality of administrative procedures practiced in our universities came to an average degree for four areas: (emotional attachment to the institution, services it provides, and visionary leadership, and work environment), with a low degree in the two areas (financial performance and social responsibility), which is what was found in the study (Shakhatra and Tarawneh, 2019).

We move on to the study (Dursun \& Gumussoy, 2021), which aims to show the factors that affect the reputation of universities and make them competitive universities seeking to attract the best students, through their systematic plans to improve their reputation with stakeholders. By studying the variables (services, attractiveness, emotion, and their impact on the reputation of universities) from the point of view and opinions of stakeholders. This study was carried out using the descriptive survey method. The sample (1000 individuals) targeted a community of stakeholders (current students, alumni, academics, and administrative staff). The results of the study confirmed the impact of the quality of services and the emotional dimension on the reputation of universities, in addition to proving that employee competence, academic leadership and student orientation had an indirect impact on the reputation of universities.

While the study (Kaushal et al, 2021), which came with the failure to explore and test the integrated relationships between the university's reputation and its main keys, by studying the variables (image, quality, value, satisfaction, and reputation) and showing the relationship and impact among them, the study followed the descriptive survey method, where the Data collection from the study population, which included a group of students in a major private university in North India. (360 questionnaires out of the total that was distributed), and the results came to confirm that the construction of the image was found to significantly affect the perceptions of students' quality, in addition to the important satisfaction, attachment, value, and reputation. As it turns out, there is an effect of students' association with the university's reputation.

The study (Miotto et al, 2020) dealt with research and analysis to increase understanding extensively on the issue of legitimacy and reputation, which are considered intangible assets and have a clear impact on gaining sustainable competitive advantage in higher education institutions, and here the researcher tries to measure reputation and its impact on legitimacy, which would create a state of sustainable competitive advantage for universities. Through the use of the field descriptive approach, the study variables (legitimacy, reputation, and competitive advantage) were measured through the questionnaire study tool, as they were distributed to the study sample (509 faculty members) from (47) different Spanish universities. The results reached by the researchers were: that there is a positive and meaningful relationship between reputation and legitimacy, as well as between reputation and the dimensions of legitimacy (pragmatic, ethical, and cognitive legitimacy), however, the hypotheses that indicated the impact of the dimensions of reputation (innovation, services, and performance) on legitimacy were uncertain, While there is a significant and positive relationship between the other three dimensions (social responsibility, governance, and work climate) with legitimacy, which in turn affects the competitive advantage.

We move our research to further in-depth details to reveal and highlight the concept of the brand for higher education institutions in particular (the Ministry of Higher Education) and the management of reputation in them, by knowing the role of communication in building reputation, to find that building a strong brand and identity for the educational institution necessarily means paying attention to the various aspects that affect And it is enhanced in building its competitive reputation, which emerged in the aspect of advertising and planned strategic promotion, which increases the organization's attraction and raises its identity to the level of competition, and this is what we found in the study (Samir \& Sobeih, 2020).

And from the researchers' keenness to gain more knowledge of the facts that others have reached in this regard, they reconsidered the issue of the practical importance of applying total quality management in the higher education sector through a study they reviewed specialized in the University (Universitas Pendidikan) in Indonesia, 
whose data was obtained through observation The interview and the study of documents so that the final result after the investigation is the stability of the fact that total quality management is nothing but a vision that the educational institution can only achieve through long-term planning, and the implementation of annual quality plans that gradually push the educational institution towards achieving its vision when applied to quality management. comprehensive in their educational systems, Which will make it able to compete and win a global competitive position and obtain good results that can be used to develop and improve the quality of higher education in general, which is what a study (Kistiani \& Permana, 2019) found.

While the search for the strength of the university's organizational reputation from the students' point of view determines the amount of its organizational attractiveness and its reflection on international students in particular, and their desire to complete their educational studies after graduating from the same university in which they study. Positive relationships were found between international students' perceptions of the university's organizational reputation, and their intention to continue university and organizational attraction. It seems that their perception of the organizational reputation of the university affects the perceptions of intention to continue studying later at the same university, facts that were discovered by researchers through a study (Pola et al., 2019).

In another study, we found that some higher education institutions focus on the application of total quality in non-academic activities and that there is a failure in the application of total quality management for not taking into account the nature of higher, academic, and cultural education. The results indicated that the issues related to the implementation of total quality management in higher education are the most raised issues this field in many different types of research and studies. In addition, TQM focuses on non-academic activities, because it does not contribute to university curricula or even to the characteristics of faculty members, and this is inconsistent with quality standards in higher education institutes, and these results came in a study (Jehan et al., 2018) .

\section{Commenting on previous studies and the difference between them and the current study:}

Undoubtedly, these studies showed the strengths and weaknesses of the application of total quality management in its combined and fragmented dimensions, in a detailed and extensive manner, in contrast to what was shown by the results in terms of organizational reputation, which studies dealt with in a non-expansive manner, and this study agreed with previous studies in certain details, However, it was extensively specialized in showing the impact of the application of total quality on the organizational reputation of one of the most important Jordanian public universities, namely (The University of Jordan), which obtained special international accreditation certificates. And the ISO 9001/2015 certificate, which is an integral part of the applications of the principles of the philosophy of total quality management, which is concerned with excellence and quality in all that the university offers, and because it is now seeking to apply for the Distinguished University Award, which calls for research into the impact on its organizational reputation.

\section{Method and Procedure}

This part includes a presentation of the study methodology and its sample, the data collection tool that was used, and procedures for finding validity, reliability, and statistical data in data analysis.

\section{Study Approach}

The descriptive survey method was used in the data collection process.

\section{Study community}

The study population consisted of faculty members at the University of Jordan, which numbered (1495) faculty members.

\section{The study sample}

The intended (meaningful) sample was selected to obtain the required information in a number of (350) individuals, based on the experiences related to the subject of the study and represented by this sample, where (Patton) confirms that the need to access rich and accurate information about a situation in the targeted sample is sufficient for the need to Statistical representation in probabilistic sampling (Al-Najjar, Al-Najjar \& Al-Zoubi, 2019, 121).

\section{Study tool}

To achieve the objectives of the study, the study tool represented by the questionnaire was developed, in order to reveal the impact of the application of total quality management on the institutional reputation of the University of Jordan. The areas included in the tool were identified, as they included two variables (independent and dependent) (independent variable - total quality management) that included five dimensions: commitment of senior management / continuous improvement / individual participation / focus on the beneficiary / training and development, while it included (the dependent variable - Organizational reputation) five dimensions: 
attractiveness / strength of financial position / social responsibility / creativity / quality of service. The questionnaire's paragraphs included a total of (50 questions) that dealt with the dimensions of all variables.

\section{Validity of the tool}

\section{A- Apparent honesty:}

To verify the validity of the tool, the content validity method was adopted by presenting it in its initial form to a group of arbitrators, from university professors specialized in educational administration, public administration, and business administration. The final tool.

\section{B - The validity of the internal consistency:}

The validity of the internal consistency of the questionnaire was confirmed by calculating the correlation coefficients between all the axes and the total scores of the questionnaire, as the correlation coefficients between each axis and the total score were a factor for the resolution to be high, and as shown in Table No. (1) Below:

Table 1. Credibility

\section{Reliability Statistics}

\begin{tabular}{|c|c|}
\hline Cronbach's Alpha & N of Items \\
\hline 0.744 & 50 \\
\hline
\end{tabular}

\section{$0.70 \leqq$ Cronbach's Alphiad $(0.744)<0.900$}

This means that the degree of credibility of the answers to the questionnaire questions was good.

Analysis of the variables and dimensions of the study:

Frequencies tables:

Table 2. Frequency Table

\begin{tabular}{|c|c|c|c|}
\hline \multicolumn{4}{|c|}{ Statistics } \\
\hline & & Job title & Years of Experience \\
\hline \multirow{3}{*}{$\mathrm{N}$} & \multirow{3}{*}{ Valid Missing Mode } & 270 & 270 \\
\hline & & 0 & 0 \\
\hline & & 2.00 & 2.00 \\
\hline
\end{tabular}

Table 2. Indicates the number of questionnaires that were subjected to statistical analysis, which numbered (270), and there was no exclusion of any of them at all.

Table 3. Frequency table (job title of the sample members)

Frequency Table

\begin{tabular}{|c|r|c|c|c|}
\hline Job title & Frequency & Percent & Valid Percent & Cumulative Percent \\
\hline \multirow{4}{*}{ Prof } & 58 & 21.5 & 21.5 & 21.5 \\
& 98 & 36.3 & 36.3 & 57.8 \\
Associate Prof & 40 & 14.8 & 14.8 & 72.6 \\
& 12 & 4.4 & 4.4 & 77.0 \\
Valid & 62 & 23.0 & 23.0 & 100.0 \\
& Assistant Prof & 100.0 & 100.0 & \\
Lecture & 270 & &
\end{tabular}

Table 3 indicates the percentages of repeating academic ranks for members of the targeted sample, which came in high rates in favor of the rank of (Associate Professor) and the rank of (Teacher), followed by the rank of (Professor), then the rank of (Assistant Professor) and came in the lowest Rank repeat rate (full-time lecturer). 
Table 4. (Number of years of experience for sample members)

\begin{tabular}{|c|c|c|c|c|}
\hline Years of Experience & Frequency & Percent & $\begin{array}{r}\text { Valid } \\
\text { Percent } \\
\end{array}$ & $\begin{array}{c}\text { Cumulative } \\
\text { Percent }\end{array}$ \\
\hline \multirow{2}{*}{ Less than 5 years } & 56 & 20.7 & 20.7 & 20.7 \\
\hline & 89 & 33.0 & 33.0 & 53.7 \\
\hline \multirow[t]{2}{*}{5 Years to less than 10 years Valid } & 44 & 16.3 & 16.3 & 70.0 \\
\hline & 81 & 30.0 & 30.0 & 100.0 \\
\hline \multirow{2}{*}{$\begin{array}{r}10 \text { Years for less than } 15 \\
15 \text { Years and over }\end{array}$} & 270 & 100.0 & 100.0 & \\
\hline & & & & \\
\hline Total & & & & \\
\hline
\end{tabular}

While Table No. (4) shows us the frequency of percentages for the number of years of experience for the sample members, which came in favor of years of experience (from 5 years to less than 10 years), followed by (15 years and more), then (less than five years) and years of experience (10 years for less than 15) ranked last. This indicates the good experience enjoyed by the faculty members (sample members), whose answers are expected to be honest and close to reality, which gives better results for the study by virtue of their academic experience and their contemporary with what is new in the plans and strategies of the university.

\section{Table 5. Crosstabs}

\section{Count}

\begin{tabular}{|c|c|c|c|c|c|c|}
\hline & \multicolumn{4}{|c|}{ Years of Experience } & \multirow[t]{2}{*}{ Total } \\
\hline & & $\begin{array}{c}\text { Less than } 5 \\
\text { years }\end{array}$ & $\begin{array}{l}5 \text { Years to less than } 10 \\
\text { years }\end{array}$ & $\begin{array}{l}10 \text { Years for less } \\
\text { than } 15\end{array}$ & $\begin{array}{l}15 \text { Years and } \\
\text { over }\end{array}$ & \\
\hline \multirow{6}{*}{ Job title } & Prof & 8 & 14 & 14 & 22 & 58 \\
\hline & \multirow{5}{*}{$\begin{array}{l}\text { Associate } \\
\text { Prof } \\
\text { Assistant Prof } \\
\text { Lecture } \\
\text { Teacher }\end{array}$} & 22 & 31 & 17 & 28 & 98 \\
\hline & & 8 & 15 & 6 & 11 & 40 \\
\hline & & 4 & 4 & 0 & 4 & 12 \\
\hline & & 14 & 25 & 7 & 16 & 62 \\
\hline & & 56 & 89 & 44 & 81 & 270 \\
\hline
\end{tabular}

As for Table 5 Cross tabulation (job title x number of years of experience), which shows the intersection between the number of faculty members who were targeted in terms of job title and number of years of experience.

Table 6. Table for testing the normal distribution

\section{Normal distribution test}

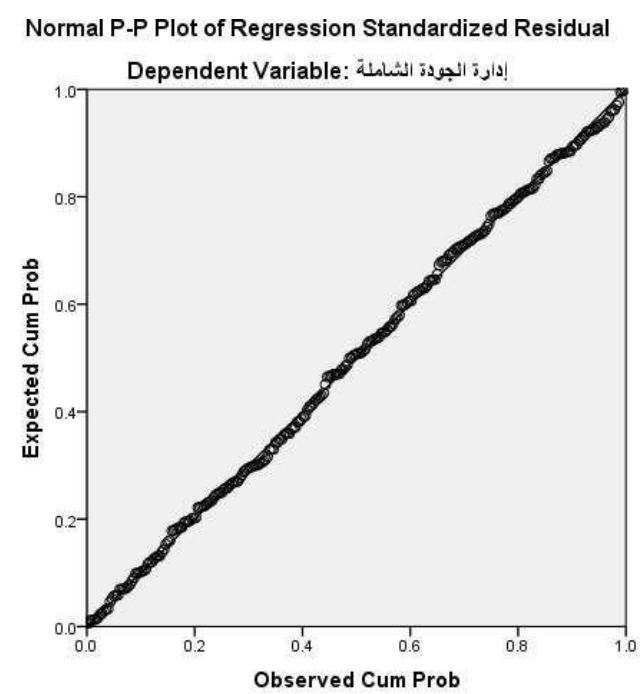

Chart 6 Shows the normal distribution test for the data collected through the study tool, which confirms the 
validity of using this data for a normal distribution.

Table 7. Linear Regression

\section{Regression}

\section{Descriptive Statistics}

\begin{tabular}{|c|c|c|c|}
\hline & Mean & Std. Deviation & N \\
\hline Total Quality Management & 3.241 & .4177 & 270 \\
\hline Creativity S (dependent & 3.2096 & .61703 & 270 \\
\hline Service quality S (dependent) & 3.1652 & .62641 & 270 \\
\hline Financial Strength S (dependent) & 3.2711 & .64363 & 270 \\
\hline Social Responsibility S (dependent) & 3.2089 & .68651 & 270 \\
\hline Attractiveness S (dependent) & 3.3096 & .64259 & 270 \\
\hline
\end{tabular}

Table 7 Shows the independent and dependent variables that were included in the linear regression analysis, as well as the degree of deviation of the values from them, as it turns out that there is no divergence or dispersion in the answers.

Table 8. Analyzes the Relationships between the variables

\section{Correlations}

\begin{tabular}{|c|c|c|}
\hline & & TQM \\
\hline & Total Quality Managemen & 1.000 \\
\hline & Creativity S (dependent & .431 \\
\hline \multirow[t]{6}{*}{ Pearson Correlation } & Service quality $\mathrm{S}$ (dependent & .377 \\
\hline & Financial Strength S (dependent & .346 \\
\hline & Social Responsibility S (dependent) & .362 \\
\hline & Attractiveness S (dependent) & .254 \\
\hline & Total Quality Managemen & \\
\hline & Creativity S (dependent & 000 \\
\hline \multirow[t]{4}{*}{ Sig. (1-tailed) } & Service quality $S$ (dependent & .000 \\
\hline & Financial Strength S (dependent & .000 \\
\hline & Social Responsibility S (dependent) & .000 \\
\hline & Attractiveness $\mathrm{S}$ (dependent) & .000 \\
\hline
\end{tabular}

Pearson Correlation

Table 9. Analyzes the relationships between the variables

Case Processing Summary

\begin{tabular}{|l|l|r|r|}
\hline & & $\mathrm{N}$ & \multicolumn{2}{|c|}{$\%$} \\
\hline Cases & Valid Excluded $^{\mathrm{a}}$ & 270 & 100.0 \\
\hline & Total & 0 & .0 \\
\hline
\end{tabular}

a. Listwise deletion based on all variables in the procedure.

It is clear to us from Table No. (8 and 9) the relationship between the independent and dependent variable, where we note the high value of the criterion (creativity) that is directly affected by the independent variable (total quality management) value of $\alpha \leq 0.05$, and this means that we reject the main hypothesis that:

There is no statistically significant effect at the level $(\alpha \leq 0.05)$ for the application of total quality management 
with its dimensions (focus on the beneficiary /commitment of senior management / continuous improvement /participation of working individuals /training and development) on the organizational reputation with its combined dimensions (creativity/ service quality /strength of the center) Financial/Social Responsibility/Gravity) at the University of Jordan.

Since there is a significant direct relationship between the independent variable and the dependent variables according to the value of (Pearson Correlation), where all values are positive and direct according to Sig = $0.000007<0.05$.

Thus, we accept the alternative hypothesis:

There is a statistically significant effect at the level $(\alpha \leq 0.05)$ of the application of total quality management with its dimensions (focus on the beneficiary / commitment of senior management / continuous improvement / participation of working individuals / training and development) in the organizational reputation with its combined dimensions (creativity / service quality / strength of financial position). / Social Responsibility / Gravity) at the University of Jordan.

Table 10. Variables Entered/Removed ${ }^{\mathrm{a}}$

\begin{tabular}{|l|c|c|l|}
\hline Model & Variables Entered & Variables Removed & Method \\
\hline & $\begin{array}{c}\text { Attractiveness S (dependent Service } \\
\text { quality S (dependent) Creativity S } \\
\text { (dependent) Financial Strength S } \\
\text { (dependent) }\end{array}$ & & \\
& Social Responsibility S (dependent) & & \\
\hline
\end{tabular}

. Dependent Variable: TQM

b. All requested variables entered.

$\mathrm{S}$ (standard)

Where we note from Table (10) the method of Entry (entered/all dimensions were entered) and no independent variable was excluded from the study, and all the entered criteria were adopted.

Table 11. Summary of the Form

Model Summary ${ }^{\text {b }}$

\begin{tabular}{|l|r|r|r|r|}
\hline Model & R & R Square & Adjusted R Square & $\begin{array}{c}\text { Std. Error of the } \\
\text { Estimate }\end{array}$ \\
\hline 1 & $.592^{\mathrm{a}}$ & .351 & .338 & .3398 \\
\hline
\end{tabular}

a. Predictors: (Constant), Attractiveness standard, creativity standard, service quality standard, financial

strength standard, social responsibility standard.

b. Dependent Variable:Total Quality Management

Table 12. Analysis of Variance

ANOVA $^{\mathrm{a}}$

\begin{tabular}{|l|l|l|l|l|l|l|}
\hline Model & Sum of Squares & Df & Mean Square & F & Sig. \\
\hline & Regression & 16.459 & 5 & 3.292 & 28.507 & $.000^{\mathrm{b}}$ \\
\hline 1 & Residual & 30.485 & 264 & .115 & & \\
\hline & Total & 46.944 & 269 & & & \\
\hline
\end{tabular}

a. Dependent Variable: TQM

b. Predictors: (Constant), Attractiveness standard, creativity standard, service quality standard,

financial strength standard, social responsibility standard .

We note through Table No. (11) (Model summary) that the coefficient of determination (R Square/r2) for the criteria (the criterion of attractiveness, the criterion of creativity, the criterion of service quality, the criterion of 
strength of financial position, the criterion of social responsibility) amounted to (35.1\%) of the variance in total quality management.

While Table (12) (Anova) indicates that the value of $(\mathrm{F})$ reached $((28,507)$ at a confidence level $(\mathrm{Sig}=0.000)$, and this confirms the significance of the regression at the level $(\mathrm{P} \leq 0.00)$ and at one degree of freedom (5).

Table 13. Transactions

\section{Coefficients $^{\mathrm{a}}$}

\begin{tabular}{|c|c|c|c|c|c|c|c|c|}
\hline \multirow[t]{2}{*}{ Model } & \multicolumn{2}{|c|}{$\begin{array}{l}\text { Unstandardized } \\
\text { Coefficients }\end{array}$} & \multirow{2}{*}{$\begin{array}{c}\text { Standardized } \\
\text { Coefficients }\end{array}$} & \multirow[t]{2}{*}{$\mathrm{T}$} & \multirow[t]{2}{*}{ Sig. } & \multicolumn{3}{|c|}{ Correlations } \\
\hline & $\mathrm{B}$ & $\begin{array}{c}\text { Std. } \\
\text { Error }\end{array}$ & & & & Zero-order & Partial & Part \\
\hline \multirow{6}{*}{$\begin{array}{l}\text { (Constant) } \\
\text { Creativity S (dependent } \\
\text { Service quality S (dependent) } \\
\text { Financial Strength S (dependent) } \\
\text { Social Responsibility S } \\
\text { (dependent) } \\
\text { Attractiveness S } \\
\text { (dependent) }\end{array}$} & 1.248 & .173 & & 7.217 & .000 & & & \\
\hline & .186 & .036 & .274 & 5.131 & .000 & .431 & .301 & .254 \\
\hline & .125 & .036 & .187 & 3.472 & 001 & .377 & 209 & .172 \\
\hline & .128 & .035 & .197 & 3.704 & .000 & .346 & .222 & .184 \\
\hline & .115 & .033 & .190 & 3.507 & .001 & .362 & .211 & .174 \\
\hline & .064 & .034 & .099 & 1.869 & .063 & .254 & .114 & .093 \\
\hline
\end{tabular}

a. Dependent Variable: Total Quality Management

We note from the coefficients that the value of $\beta /$ Beta for the individual relationships between each independent variable and the dependent variable reached the highest for the creativity criterion (.274) at a confidence level $(\mathrm{Sig}=0.000)$, and that the attractiveness criterion has no significant impact on the management of The overall quality because the value of ( $\beta$ ) / Beta) for the criterion of attractiveness (.099) at a confidence level (Sig $=0.063)$, a value greater than $(0.05)$, and this confirms the significance of the different coefficients for the dimensions of the independent variable at the level $(\mathrm{P} \leq 0.05)$.

The foregoing analysis calls for what we mentioned earlier in the analysis by not accepting the nihilistic hypothesis, and accepting the alternative hypothesis that says:

There is a statistically significant effect at the level $(\alpha \leq 0.05)$ for the application of total quality management with its dimensions (focus on the beneficiary/commitment of senior management/continuous improvement/participation of working individuals/training and development) on the organizational reputation with its combined dimensions (creativity/service quality/financial performance/ Social Responsibility/Gravity) at the University of Jordan.

\section{Discussing the Results of the Study}

Results of the first question: What is the level of application of total quality management in its dimensions at the University of Jordan?

The answer to this question becomes clear to us through the results of the analysis that demonstrated a rise in the dimensions of organizational reputation, which in turn confirms that the degree of application of total quality management at the University of Jordan is high, as it was reflected in the high dimensions of organizational reputation in order as follows: the dimension of creativity, followed by the dimension of service quality, Then the dimension of social responsibility, followed by the dimension of the strength of the financial position, while the dimension of attractiveness was the least influential dimension of applying the principles of total quality management.

This result is attributed to the University of Jordan's recent interest in its academic and administrative reputation, and its keenness to adopt the principles of total quality management in its executive and operational

plans, to ensure the provision of the best academic services andprograms

Results of the second question: Is there a statistically significant effect at the level $(\alpha \leq 0.05)$ for the application of total quality management on the organizational reputation of the University of Jordan?.

Which was confirmed by the previous results, especially the results of Table No. (13/ Transactions) that there is a statistically significant effect at the level $(\alpha \leq 0.05)$ for the application of total quality management in its dimensions (focus on the beneficiary / commitment of senior management/ continuous improvement / participation of working individuals / training and development ) in the organizational reputation with its combined dimensions 
(creativity / quality of service / strength of financial position / social responsibility / attractiveness) at the University of Jordan.

The relationships were significant confirming the significance of the different treatments for the dimensions of the independent variable at the level $(\mathrm{P} \leq 0.05)$, which proves the existence of the effect. This result agreed with the study of Hamidi (2020), and the study of Shakhatra \& Tarawneh (2019).

\section{Recommendations}

In light of the results that have been reached, the researchers recommend the following:

-Maintaining the application of total quality management in the University of Jordan more effectively with continuous development and improvement.

Raising the percentage of university employees' contribution to the decision-making process, which in turn reflects creative ideas and talents that raise the university's reputation.

Allocating financial and human resources to increase the efficiency of applying the principles of quality management in all educational and administrative systems at the university.

Working on marketing the University of Jordan (its services and academic programs) locally, Arabian, and internationally, so that the marketing process improves the image of the university in the minds of the stakeholders (current and potential), and thus attracts new stakeholders (students / investors).

-Increasing the university's contribution to social responsibility to raise its reputation and attract supportive partners (local community partners from the public and private sectors).

\section{References}

Abd al-Rahim, A. H. A., Abd al-Aziz, A. A. H., \& al-Hussein, A. B. (2020). Performance evaluation in higher education institutions from the perspective of total quality management. International Journal of Economics and Business, 9(2), 365-381. Refad Center for Studies and Research, Jordan.

Abdelaziz, M. M. A. (2019). Reputation management is an approach to achieving the competitive advantage of university education institutions in Egypt. Educational Journal for Adult Education, 1(4), 350-283. College of Education, Adult Education Center, Assiut University, Arab Republic of Egypt.

Abu Al-Nasr, M. M. M. (2015). Total Quality Management: Japanese Kaizen Strategy for Organizational Development. Arab Republic of Egypt, Cairo: The Arab Group.

Abu Asbaa, A. F. A. Y. (2020). The role of total quality management in achieving competitive advantage in Yemeni private universities: an analytical study. National University Journal, 14, 203-237. National University, Sana'a, Republic of Yemen.

Akbar, A., Mahmoud., A. H., \& Mohmmad., A. S. S. (2019). Total Quality Management System in an Education Environment: The Case of a Private University in Bahrain. Journal of Reviews on Global Economics, 8, 717-729. https://doi.org/10.6000/1929-7092.2019.08.62

Al-Damen, R. A. (2017). The Impact of Total Quality Management on Organizational Performance Case of Jordan Oil Petroleum Company. International Journal of Business and Social Science, 8(1).

Al-Habib, B. (2019). Total Quality Management (concept, basics, conditions of application). The Egyptian Arabic Republic. Cairo: The Modern Academy for University Books.

Al-Najjar, F., Al-Najjar, N. J., \& Al-Zoubi, M. R. (2018). Scientific Research Methods - An Applied Perspective. Jordan, Amman: Dar Al-Hamid for publishing and distribution.

Al-Nuaimi, M. A. A., l-Tarawneh, R. A., \& Al-Shura, A. A. (2020). The impact of total quality management in the smart organization: an applied study in computer information systems companies. International Journal of Economics and Business, 8(2), 293-307. Refad Center for Studies and Research, Jordan.

Al-Sarhan, A. F. (2020). The impact of applications of total quality standards and academic accreditation on improving the individual and institutional performance of Jordanian public universities. Journal of Islamic Management and Leadership, 6(1), 14-38. International Organization for Islamic Marketing.

Al-Shakhatra, A. A., \& Al-Tarawneh, A. Y. (2019). The reality of administrative procedures practiced to raise the institutional reputation of Jordanian public universities from the point of view of academic administrations. Jordan Educational Journal, 4(4), 215-191. Jordan Association for Educational Sciences, Amman, Jordan.

Al-Shehri, M. H., \& Al-Shahrani, S. A. N. (2020). The impact of applying total quality standards on job 
performance: An empirical study on workers in the Saudi Red Crescent Authority - Kingdom of Saudi Arabia. Journal of Economic, Administrative and Legal Sciences, 4(10), 122-143. National Research Center, Gaza.

Amir, A. A., \& Salah, E. A. Z. (2017). Reflected customer management in enhancing the reputation of the organization: an exploratory study of a sample of Iraqi private banks in the city of Baghdad. The Islamic University Journal, 22(94), 52-75. The Islamic University, Gaza, Palestine.

Attia, M. A. (2015). Total quality and curriculum. The Arab Republic of Egypt, Cairo: Dar Al-Manhaj for Evil and Distribution.

Dursun, O., \& Gumussoy, C. A. (2021). The effects of quality of services and emotional appeal on university reputation: stakeholders' view. International Journal of Emerging Markets. Emerald Publishing Limited. https://doi.org/10.1108/QAE-08-2020-0104

Eckert, C. H. (2016). Corporate reputation and reputation risk: definition and measurement from a (risk) management perspective. Department of Insurance Economics and Risk Management Friedrich-Alexander University Erlangen-Nürnberg (FAU). https://doi.org/10.1108/JRF-06-2016-0075

Ghoneim, A. M. (2018). Total Quality Management (2nd ed.). Arab Republic of Egypt, Mansoura: Modern Library for Publishing and Distribution.

Griffin, R. W. (2016). “Management” South-Western, Cengage Learning (11st ed.). USA.

Hamidi, M. (2020). The impact of the principles of total quality management on the performance of universities. Journal of Economics and Sustainable Development, 3(1), 72-84. University of Martyr Hama Lakhdar El Wadi - Faculty of Economics, Commercial and Management Sciences, Algeria.

Imran, H. A. S. A., Anqani, N. A. S., \& Idris, H. A. (2020). An exploratory study of the opinions of a sample of faculty members at the Faculty of Economics, Abha University. Journal of Studies and Research, 12(1), 209-233. University of Aljelfa.

Jehan, N., Malik, F., Ali, A., \& Waheed, U. (2018). The Impact of Total Quality Management (TQM) in Higher Education: A Qualitative Insight of Higher Educationin Universities. Retrieved from https://www.researchgate.net/publication/326010290

Kaushal, V., Jaiswal, D., Kant, R., \& Ali, N. (2021). Determinants of university reputation: conceptual model and empirical investigation in an emerging higher education market. International Journal of Emerging Markets, Emerald Publishing Limited. https://doi.org/10.1108/IJOEM-12-2020-1494

Kawengian, K. D., Pangemanan, S. S., \& Tielung, M. V. (2019).The Influence of Reputation, Distance and Involuntary Switching on Customer Switching behavior at PT. Jne in Manado. Jurnal EMBA: Jurnal Riset Ekonomi, Manajemen, Bisnis dan Akuntansi, 7(1), 61-70.

Khayukha, Z. M. H., \& Al-Obaidi, S. A. H. (2020). The principles of total quality management and their impact on organizational performance: an exploratory study of the opinions of a sample of university leaders in a group of Iraqi universities. Anbar University Journal of Economic and Administrative Sciences, 12(29), 239-259. Uni versity of Anbar, College of Administration and Economics.

Kistiani., D. P., \& Permana, J. (2019). The Importance of Application Total QualityManagement at Higher Education. Advances in Social Science, Education and Humanities Research, 400, 177-180.

Kooli, C. (2019). Governing and managing higher education institutions: The quality audit contributions. Evaluation and program planning, 77, 101713. https://doi.org/10.1016/j.evalprogplan.2019.101713

Kooli, C., \& Abadli, R. (2021). Could Education Quality Audit Enhance Human Resources Management Processes of the Higher Education Institutions? SAGE journals. https://doi.org/10.1177/09722629211005599

Kooli, C., Jamrah, A., \& Al-Abri, N. (2019). Learning from quality audit in higher education institutions: A tool for community engagement enhancement. FIIB Business Review, 8(3), 218-228. https://doi.org/10.1177/2319714519863559

Lakassmi, K., \& Jamil, A. (2020). The impact of the application of total quality management on gaining competitive priorities: a case study of the cement company in Sur El Ghazlan - SCSEG - Bouira State. Majma`at al-Ma`rifa Journal, 6(2), 312-329, Ali Kafi University Center, Tindouf.

Madi, K. I., \& Al-Bashiti, S. O. (2020). The mediating role of organizational commitment in the impact of 
quality of work life on the Palestinian organizational reputation. Journal of the Islamic University for Economic and Administrative Studies, 28(4), 20-47. The Islamic University of Gaza - Scientific Research and Graduate Studies Affairs.

Miotto, G., Del-Castillo-Feitob, C., \& Blanco-Gonzálezb., A. (2020). Reputation and legitimacy: Key factors for Higher Education Institutions'sustained competitive advantage. Journal of Business Research, 112, 342-353. https://doi.org/10.1016/j.jbusres.2019.11.076

Pola., S., Guncavd, G., \& Arslan, Y. (2019). The Impacts of a University's Organizational Reputation and Organizational Attraction on Students' Intention to Pursue. Eurasian Journal of Educational Research, 84, 213-236. https://doi.org/10.14689/ejer.2019.84.10

Samir, R., \& Sobeih, Y. (2020, June). Institutional Brand Reputation Management within the Higher Education Institutes. (RAIS) Research Association for Interdisciplinary Studies. Conference Proceedings, 319-322.

Stevenson, W. J. (2018). Operations Management (13rd ed.). Published by McGraw-Hill/Irwin, a business unit of The McGraw-Hill Companies, Inc, New York.

Tong, C., Wong, A. T. T., \& Cheng, T. (2019). Do Corporate Social Responsibility and Safety of Food Affect Reputation? A Study of Fast-food Restaurants Industry in Hong Kong. Journal of Economics, Management and Trade, 1-18. https://doi.org/10.9734/JEMT/2019/46107

Willems, J. (2019). Leadership, Performance, and Reputation: A multi-method empirical view on the public and nonprofit sectors-Habilitation Synopsis. pp. 1-9. https://doi.org/10.31219/osf.io/np9e3

Yassin, S. I. B. (2015). The Importance of Performance Indicators in Ranking Universities at the Global Level: An Analytical Study of the Attitudes of Principals of Sudanese Governmental Universities (Performance Measurement Conference and the Application of the Key Indicators System in Enhancing Total Quality in Universities of the Arab World). Taibah University - Madinah, Volume 1, January 11-13.

Zaghlash, L. (2020). Total quality in Arab universities in the face of globalization. International Journal of Research in Educational and Human Sciences, Arts and Languages, 1(6), 38-60. University of Basra and the Center for Research and Development of Human Resources Ramah.

\section{Copyrights}

Copyright for this article is retained by the author(s), with first publication rights granted to the journal.

This is an open-access article distributed under the terms and conditions of the Creative Commons Attribution license (http://creativecommons.org/licenses/by/4.0/). 